\title{
Türk Basınında Çalışma Hayatı ve İş Güvencesi Sorunu
}

\author{
DOI: 10.26466/opus.579499
}

\author{
Mehmet Sena Kösedağ \\ * Dr. Öğr. Üyesi, Erciyes Üniversitesi, İletişim Fakültesi Öğretim Üyesi, Kayseri/ Türkiye \\ E-Posta: mskosedag@erciyes.edu.tr \\ ORCID: $\underline{0000-0003-2210-580 \mathrm{X}}$
}

\section{Öz}

Türk medyasında son dönemlerde yaşanan büyük çapl mülkiyet değişiklikleri ve ülkenin içinde bulunduğu ekonomik durum nedeniyle çok sayıla gazeteci işsiz kalarak mağdur olmuştur. Bu gelişme, Türk basını açısından öteden beri tartışma konusu olan iş güvencesi sorununu yeniden gündeme taşımıştır. Günümüzde iletişim teknolojilerinde yaşanan hızl gelişmeler, iletişimin kalitesini artırmış, basın kuruluşların teknik altyapı bakımından daha da güçlendirmiştir. Türkiye'de medya kuruluşları fiziki ve teknolojik donanım bakımından, dünyanın diğer medya kuruluşlar ile yarışır düzeye ulaşmıştır. Ancak aynı iyileşme, gazetecilerin özlük haklarına ve çalışma koşullarına yansımamıştır. Medya sektöründe görev yapan fikir iş̧̧ileri; sahip oldukları haklar, çalı̧̧ma koşulları ve iş güvencesi bakımından geçmiş yıllara oranla daha kötü koşullarla karşı karşıya bulunmaktadır. Yasaların yeterince işletilememesi nedeniyle, sektörde meydana gelen gelişmelerden ilk etkilenen kişiler fikir işçileri olmaktadır. Basında sendikalaşma oranının yerinde saydığ ülkemizde; işsiz gazeteci sayısı sektördeki büyümeye rağmen artış göstermektedir. Bu çalı̧̧ada, Türkiye'deki gazetecilerin karşı karşıya kaldı̆̆ı iş güvencesi sorunu ele alınmıştır. Literatür taraması ile yapılandırılan çalışmada, iş güvencesi yoksunluğunun basın özgürlüğüne olan etkisi değerlendirilmeye çalışılmış, bu durumun basında istihdam edilen insan kaynağının kalitesi üzerindeki etkisi sorgulanmıştır. Çalışmada, Türk basınında iş güvencesinin ilk dönemlerden itibaren bir problem olarak ortaya çıktığı, gazetecilerin yasal düzenlemelere rağmen işsizlik baskısı altında görev yaptıkları ve bu unsurların basında insan kaynağı ve basın özgürlüğ̈̈ üzerinde olumsuz etki yaptığı sonucuna varılmışıtır.

Anahtar Kelimeler: Medyada iş güvencesi, Basında insan kaynağı, Basında sendikalaşma, Medyada çalışma koşulları, Basında çalışma hayatı 


\title{
Problems Associated with Working Life and Employment Security in Turkish Press
}

\begin{abstract}
Many journalists have been unemployed and victimized due to the recent major changes in ownership in the Turkish media and the economic situation in the country. This development brought the issue of job security, which has been the subject of debate for the Turkish press, to the agenda again. The rapid developments in communication technologies today have increased the quality of communication and strengthened the press organizations in terms of technical infrastructure. Media organizations in Turkey in terms of physical and technological infrastructure, has reached the level of competition with other media organizations in the world. However, the same improvement was not reflected in the personal rights and working conditions of journalists. Opinion workers in the media sector face worse conditions than in previous years in terms of their rights, working conditions and job security. The first people to be affected by the developments in the sector are the opinion workers because of the inadequacies in the implementation of the laws. In our country where the rate of unionization in the press is stagnated; The number of unemployed journalists is increasing despite the growth in the sector. In this study, job security issue faced by journalists in Turkey has been addressed. In the study, which was structured with literature review, the effect of lack of job security on press freedom was tried to be evaluated and the effect of this situation on the quality of the human resources employed in the press was questioned. In the study, it was concluded that job security has been a problem in the Turkish press since the early periods and that journalists work under the pressure of unemployment despite legal regulations and these elements have negative effects on human resources and press freedom in the press.
\end{abstract}

Keywords: Job security in Media, Human resources in Press, Unionization in the Press, Working conditions in the Press, Work life in the Press 


\section{Giriş}

Demokratik toplumlarda, medyaya çok önemli işlevler yüklenmektedir. Haber ve bilgi akışını sağlayarak, aydınlanma sürecini oluşturan ve toplum düzeninin işleyişine katkıda bulunan temel yapılardan biri olan medya, bu nedenle yasama, yürütme ve yargıdan sonra 4 . Kuvvet olarak tanımlanmaktadır. Geleneksel anlamda medyanın üstlenmiş olduğu görev ve sorumluluklar, günümüzde belli ilkesel doğrulara bağlanmıştır. Medya kendi yapısal ve işlevsel özelliklerinin doğası gereği, kendisine yüklenen toplumsal sorumlulukları yerine getirmektedir. Ancak medyanın kendisinden beklenen işlevleri eksiksiz olarak gerçekleştirmesi için bazı koşulların tam olarak sağlanması gerekmektedir. Bu bağlamda her şeyden önce basın özgürlüğünü güvence altına alan yasaların işletilmesi zorunludur. Ayrıca serbest rekabet koşullarında, kamusal yayıncılığa imkân sağlanması ve tekelleşmenin önlenmesi de önemli bir unsur olarak görülmelidir. Bunun yanında gazetecilerin özgür ve baskıdan uzak bir biçimde ve yasal iş güvencesine sahip bir ortamda görev yapmaları sağlanmalıdır.

Türk basın tarihine bakıldığında, fikir işçisi olarak adlandırılan gazetecilerin güç koşullar altında görevlerini yerine getirmeye çalıştıkları ve büyük bölümünün iş güvencesinden yoksun olduğu görülmektedir. 1980'lerden itibaren başlayan ve günümüzde devam eden mülkiyet değişikliklerinden en çok etkilenen kesim; basın çalışanları olmuştur. Günümüzde Türk medyasının en büyük mülkiyet satışlarından biri gerçekleşmiş; bu nedenle pek çok gazeteci işsiz kalmış ve mesleklerini yapamaz hale gelmiştir. İşsiz kalan aynı zamanda sendikasız oldukları anlaşılan gazeteciler, sosyal medya dışında sorunlarını gündeme getirecek bir mecra bulamamıştır. Basında sendikalaşma çabalarının yetersiz kaldığı Türk basınında, fikir işçilerine ödenen ücretler de benzer şekilde düşük seviyede seyretmektedir. Bu nedenle, nitelikli iş gücünün basın sektöründe istihdamı mümkün olamamakta ve basın ürünlerinin kalitesi düşük seviyede seyretmektedir. Dolayısıyla, sektördeki kötü çalışma koşulları, basının işlevini yerine getirmesinin önünde önemli bir engel teşkil etmektedir. Basında iş güvencesinin olmaması, basın özgürlügü ile de ilişkilendirilebilen bir konudur. İş güvencesine sahip olamayan gazetecilerin, haber ve yorumlarında serbest hareket edemeyeceği, işsiz kalma 
endişesi ile patronaj veya farklı çevrelerin baskısı altında kendi kendine sansür uygulayabileceği kabul edilen bir gerçektir.

Bu çalışmada, Türkiye'de basın çalışanlarının özlük hakları sorunu ele alınmış, bu durumun basın özgürlügünü üzerindeki etkisi sorgulanmaya çalışılmıştır. İş güvencesi olmayan bir sektörde nitelikli personel istihdamının mümkün olup olmayacağı sorusuna cevap aranan çalışmada, günümüzde Türk basın sektöründe istihdam edilen personelin profili ortaya konmaya çalışılmıştır. Literatür taraması yöntemi ile gerçekleştirilen çalışmanın ilk bölümünde basında çalışma hayatı ile ilgili genel bir çerçeve çizilmiş, sektörde çalışma yaşamını belirleyen yasal düzenlemelere yer verilmiştir. Daha sonra Türk basınında görev yapan insan kaynağının genel özelliklerine değinilerek, iş güvencesinin basın özgürlüğü ve basındaki istihdamı ne şekilde etkilediği tartışılmıştır. Sonuç kısmında ise tespit edilen problemlerin çözümüne dair görüşler dile getirilmiştir.

\section{Basında Çalışma Hayatını Şekillendiren Yasal Düzenlemeler}

Türk basınında ilk gazeteler 1800'lü yıllardan itibaren çıkarılmaya başlanmıştır. İlk dönemin gazetecileri, yabancı uyrukludur ve çıardıkları gazeteler yabancı elçilikler veya dönemin padişahları tarafından finanse edilmiştir. Özel sermaye ile kurulan ve hazineden yardım almayan ilk Türkçe gazete olan Tercüman-1 Ahval'in 1860'ta yayın hayatına başlaması ile gerçek manada basın işletmeciliğinin zorlukları ortaya çımıştır. Türk gazeteciler, el tezgâhında basılan bu gazetelerde ilkel ve zor koşullar altında kalemlerini almış ve yazmaya başlamışlardır (İnuğur, 2005, s.173-185). Osmanlı'da basının toplumsal yaşantıda yer edinmeye başlaması üzerine İstanbul dışında da gazeteler yayın hayatına başlamıştır. 1860-1908 yılları arasında Osmanlı'nın uzak vilayetleri ve Anadolu'nun çeşitli illerinde 30'un üzerinde vilayet gazetesi yayınlanmıştır. Yetişmiş insan gücünün olmadığ 1 bu dönemde, zamanın aydınlarından muhabir ve yazar olarak yararlanılmış, kâğıt ve mürekkep gibi baskı malzemelerinin temininde zorluklar yaşanmış, meslekten yetişmiş mürettip ve matbaacının temininde de büyük güçlükler çekilmiştir (Erdoğan, 2007, s.30-32). 
Ülkemizde, gazetecilerin çalışma yaşamına ilişkin ilk yasal düzenleme 1938' de kabul edilen 3511 sayılı Basın Birliği Kanunu'dur. Yaygın bir uygulama alanı bulmasa da 1946'ya kadar yürürlükte kalan bu düzenleme nedeniyle gazeteciler bir oda etrafında toplanmıs,, maddi ve manevi anlamda ortak çıkarlarını korumaya çalışmışlardır (Özsever, 2004, s.33). $\mathrm{Bu}$ dönemde gazete sahipleri resmi ilan ve reklam ile çeşitli yardımlar adı altında kamudan kaynak sağlarken, işçilerin çalışma koşullarında iyileşme yönünden bir eğilim görülmemiştir. Bu tablo Cumhuriyetin ilk yıllarında ve tek parti iktidarının son dönemlerine kadar değişiklik göstermemiştir. Çok partili sisteme geçilmesi ve Demokrat Parti'nin iktidara gelmesi ile birlikte basında özgürlük havası esmiş, gazetecilik itibar kazanmış ve kısa süre içerisinde pek çok basın organı yayın hayatına başlamıştır. İlk yıllarında basına karşı özgürlükçü bir tutum sergileyen DP iktidarı, gazetecilerin çalışma hayatına yönelik çok önemli yasal düzenlemeleri yürürlüğe koymuştur. Gazeteciliğin Türkiye'de profesyonel bir meslek haline gelmeye başlaması bu döneme denk gelmiştir. 1950'lere kadar okur-yazar oranının az olması, gazete işletmelerinin çalışanlara tatmin edici bir ücret ödememesi, bu mesleğin toplum tarafından ciddiye alınmaması, basındaki çalışma hayatını olumsuz etkileyen belli başlı faktörler arasında bulunmaktadır.

Yüzylla yakın bir zaman diliminde sosyal güvenlikten yoksun ve zor şartlar altında görev yapan Türk gazeteciler, 13 Haziran 1952'de çıarılan "Basın Mesleğinde Çalışanlarla Çalıştıranlar Arasındaki Münasebetlerin Tanzimi Hakkındaki Kanun" sayesinde sosyal haklarını elde etmişlerdir. Gazeteciliği dolaylı de olsa bir meslek olarak tanımlayan bu yasa ile birlikte mesleğin çalışma esasları belirlenmiştir. Ayrıca bu kanun, dönemin çalışma hayatına bakıldığında, reform sayılabilecek birçok hüküm içermektedir. Yalnızca devlet memurlarının yararlandığı yıllık ücretli izin hakkı bu yasayla birlikte gazetecilere de tanınmış, ayrıca gazetecilerin işverenle, içinde işin türü, ücreti, gazetecinin kıdemi gibi kayıtların yer aldığı bir yazılı sözleşme yapması zorunluluğu getirilmiştir. Sözleşmenin bildirim olmaksızın feshedilememesi, işten çıarım halinde tazminat ödenmesi zorunluluğu, haftalık tatil hakkı, askerlikte ücret alma hakkı, sendika kurma hakkı ve sosyal sigortalara tabi olma zorunluluğu gibi haklar da sağlanmıştır. Bu düzenleme çok partili yaşama geçildikten sonra Türkiye'de çıkarılan ilk iş kanunu olma özelliğini taşı- 
maktadır ve içeriği açısından dönemine göre oldukça ileri bir düzeydedir (Kösedağ, 2016; s.53, Çakır, 2007, s.173-174).

Sınırlı bir uygulama alanına bulabilen bu düzenleme, 1960 darbesi ile iş başına gelen Milli Birlik Komitesi tarafından yeniden ele alınmıştır. 10 Ocak 1961'de yürürlüğe giren 212 sayılı Fikir İşçileri Kanunu, basın sektöründe çalışanlara yeni haklar tanımıştır. Yeni kanunla mesleğe ilk giriş tarihi kıdem başlangıcı olarak kabul edilmiş, gazetecilerin ailesine kıdeme göre ölüm tazminatı verilmesi sağlanmış ve gazetelerin kapanması durumunda gazetecilere iki aylık maaşla birlikte kıdeme göre ödenek verilmesi şartı getirilmiştir. İstifa eden gazeteciye kıdem tazminatı verilmesi; aylıkların peşin olarak ödenmesi; gece çalışanlara haftada iki gün izin verilmesi; kâr eden gazetecilere her yıl bir maaş ikramiye verilmesi gibi olanaklar da yasanın kazanımları arasında yer almıştır. Ayrıca fikir işçileri ile ilgili iş anlaşmazlık davalarının ticaret mahkemeleri yerine, iş mahkemelerinde görülmesi kararlaştırılmıştır (Topuz, 2003, s.228229).

Basın İş Kanunu'nun yürürlüğe girmesi, basın tarihinde görülmemiş olayların meydana gelmesine neden olmuştur. Kanun, fikir işçilerini memnun ederken, gazete patronlarının büyük tepkisini çekmiş, gazete sahipleri, söz konusu yasayı protesto etmek için 10 Ocak 1961'de ortak bir bildiri yayımlayarak, gazetelerini 3 gün süreyle çıkarmayacaklarını duyurmuştur. Bildirinin yayımlandığı Akşam, Cumhuriyet, Dünya, Milliyet, Tercüman, Vatan, Yeni Sabah, Hürriyet ve Yeni İstanbul gazeteleri 3 gün süreyle yayımlanmamıştır. Yasayı destekleyen basın işçileri ise çeşitli protesto eylemleri gerçekleştirip, bir taraftan da halkı gazetesiz bırakmamak adına BASIN adıyla bir gazete çıkarmıştır. Gazetenin ilk sayısının başyazısında şu ifadelere yer verilmiştir: "Temel hak ve hürriyetlerimizin gerçekten kısıtlandığı, yalnız basının değil bütün memleketin gerçekten eşi görülmemiş bir tehlikenin içine sokulduğu günlerde bile gazetelerini kapatmayan ve protesto yoluna gitmeyen gazete sahiplerinin, şimdi bir ilan kurumu için yaptıkları bu hareket, basın tarihimizde herhalde şerefli bir yer kaplamayacaktır. Gazete çıkarmak çorap fabrikası işletmeye benzemez. Basın bir kamu hizmetidir." Düzenlemenin Resmî Gazete'de yayımlanarak yürürlüğe girdiği tarih olan 10 Ocak, "Çalışan Gazeteciler Bayramı" olarak ilan edilmiş ve halen günümüzde kutlanmaktadır (Çakır, 2007; s.175; Topuz, 2014, s.231). 
MBK hükümeti döneminde gazeteciler, 15 Temmuz 1963'te kabul edilen ve 24 Temmuz'da yürürlüğe giren 274 sayılı Sendikalar Yasası ile toplu sözleşme, 275 sayılı Grev ve Lokavt Yasası'yla da grev yapma hakkı elde etti. Bu gelişme ile birlikte, 1952'de kurulan İstanbul Gazeteciler Sendikası, 30 Eylül 1963 tarihinde Türkiye Gazeteciler Sendikası (TGS) adıyla yeniden yapılandı (Özsever, 2004, s.90-101). Ancak bu düzenlemeler tam anlamıyla basın çalışma hayatında uygulamaya geçirilmemiş, gazete patronları farklı taktikler uygulayarak, eski çalışma düzenini sürdürmek istemişlerdir. Bu dönemde yapılan toplu iş sözleşmelerinin işyerleri düzeyinde kaldığı, işyeri kolu düzeyinde sözleşme yapılmadığı görülmektedir. Türkiye'de ilk toplu iş sözleşmesi TGS ile Milliyet ve Cumhuriyet gazeteleri arasında 1 Şubat 1964 tarihinde imzalanmış ve bu kurumlarda görev yapan gazetecilerin çalışma koşullarında iyileşme yaşanmiştır ( Tuncay, 1989, s.109).

1980 yılında yapılan askeri darbeden toplumun tüm kesimleri gibi basın da olumsuz etkilenmiş, sendikalar 3 yıl süreyle kapatılmıştır. 1952 yılında kabul edilen Basın İş Kanunu (BİK) bu dönemde yürürlükte kalmış, bununla birlikte kabul edilen yeni Anayasa ve değiştirilen Sendikalar Kanunu'yla da basının çalışma hayatına ilişkin yeni düzenlemeler getirilmiştir.

10 Haziran 2003'te yürürlüğe giren Yeni İş Kanunu olarak bilinen 4857 sayılı yasa ile 5953 sayılı Basın İş Kanunu'na tabi olarak görev yapan gazetecilerin de belli koşullarda iş güvencesi kapsamına alınması kararlaştırıldı. Bu yasanın bir özelliği de gazetelerin yanı sıra radyo ve televizyonlarda çalışanları da kapsama dâhil etmiş olmasıdır. 4857 sayılı yasa, esnek çalışmaya olanak sağlayan hükümleri nedeniyle eleştirilse de iş güvencesi ve özellikle sendikal örgütlenmeye imkân tanıyan yönüyle olumlu bulunmuştur.

Basın İş Kanunu'na göre çalışan gazetecilerin de aralarında bulunduğu bazı meslek grupları, fiili hizmet zammı olarak adlandırılan ve kamuoyunda "yıpranma hakkı" olarak adlandırılan uygulama ile diğer meslek mensuplarına oranla erken tarihte emekli olma hakkı elde edebiliyorlardı. Ancak, 2008'de 5510 sayılı Sosyal Sigortalar ve Genel Sağlık Sigortası Kanunu'nda bir değişiklik yapılarak gazetecilerin bu hakkı ellerinden alındı. Basın meslek örgütlerinin uzun uğraşları sonucu, bu 
hak 2013 tarihinde yeniden sağlandı ve aradan geçen 5 yıllık sürenin geriye doğru telafi edilmesi hakkı tanındı.

\section{Basın Sektöründe İş̧ Güvencesi Sorunu}

Türk basın tarihine bakıldığında, fikir işçilerinin çalışma şartlarının ilk dönemlerden itibaren sorunlu olduğu görülmektedir. Gazeteciliğin meslek olarak tanımlandığı, toplum tarafından itibar görmeye başladığı ve bu nedenle kapsamlı bir sosyal güvenlik yasasının yürürlüğe girdiği 1952'den itibaren hak mücadelesine girişen basın çalışanlarının, başarılı olması için 12 yıl beklemeleri gerekmiştir. Türkiye'de ilk toplu iş sözleşmesi 1964'te yapılmış ve 2 basın kuruluşu ile sınırlı kalmıştır.

$\mathrm{Bu}$ tarihten itibaren sendikal mücadele adı altında iş güvencine kavuşmak için çaba gösteren gazeteciler, belli oranda başarı elde etmiştir. Ancak 12 Eylül darbesinden sonra uygulamaya konulan yasal düzenlemeler, gazetecileri savunmasız bırakmıştır. Çünkü 12 Eylül düzeni ile birlikte basın sektöründe çalışanların toplu sözleşme düzeni kullanılamaz hale getirilmiş, böylece sendikal hareket işlevsiz kılınmıştır. Sendikal hak ve özgürlük ihlalleri giderek artmış; basın ve gazetecilik sektöründe bu sınırlandırmalar ve ihlaller daha ciddi bir boyuta ulaşmıştır (Akkaya, 2019).

Uzun yıllar basın iş kolunda faaliyet gösteren tek sendika olan Türkiye Gazeteciler Sendikası, 1970'lı yıllarda oldukça başarılı olmuş ve ülke çapında otuzun üzerinde iş yerinde toplu sözleşme yapabilmiştir. Ancak sendikal hareketlere büyük sekte vuran 12 Eylül darbesi, basında sendikal hareketleri zayıflatmıştır. Bu dönemde çıan yasal düzenlemeler nedeniyle iş kolları değişmiştir. Basın kuruluşunun herhangi bir biriminde çalışan kişi, sendikaya üye olabiliyorken, yeni düzenleme ile sadece gazetecilerin bu sendikaya üye olabilmesi hükme bağlanmıştır. Bu durumu fırsat bilen işverenler, taşeronlaşmaya gitmiş veya fikir işçilerini, beden işçisi gibi sigortalatabilmiştir. Medyada tekelleşme artmış, sendikal haklar ve toplu sözleşme çalışanlar için lüks olarak görülmüştür. Basında ilk büyük tekelleşmeyi Doğan Holding grubu gerçekleştirmiş, sendikasızlaştırma hareketi ile birlikte basın çalışanları baskılar sonucu notere gönderilerek sendikadan istifa ettirilmiştir. İkinci büyük grup 
olan Dinç Bilgin, ilk etapta toplu sözleşme imzalamış ancak bir gün sonra çalışanlarını noter kanalıyla istifa ettirmiştir (Karahisar, 2019, s.94-95)

80 'li y1llardan itibaren uygulanan ve 90'l1 yıllarda yaygınlaşan neoliberal ekonomik politikalar nedeniyle; hızla büyüyen holdinglerin ve iktidarlara yakın sermaye gruplarının eline geçen medyada, çalışanların sayısı artmış, buna karşılık iş güvencesi, çalışma saatleri ve ücretlerde iyileşme olmamıştır. Medya organlarının sahiplik yapısı değiştiğinde, bu durumdan en çok etkilenen kesim yine işçiler olmuştur. Birçok gazeteci ve medyanın farklı alanlarında çalışan kişiler, işlerini kaybetmiştir (Ulusoy, 2012, s.334).

Basın sektöründe sendikalaşma oranı, her dönemde diğer sektörlerin çok gerisinde kalmıştır. Ülkemizde genel olarak medyada sendikalaşma oranı yüzde 10'ü geçememiştir. Toplu iş sözleşmesi kapsamına giren çalışan sayısı ise çok daha düşüktür. 2019'a gelindiğinde ülkede sendikalaşabilen işçilerin oranı yüzde 11 ile sınırlı kalmış, işçilerin sadece yüzde 7 'si toplu iş sözleşmelerinden yararlanabilmiştir. Basın iş kolunda ise sendikalaşma oranı yüzde 8 civarında, toplu sözleşmeden yararlanan gazetecilerin oranı da yarısı kadardır. 2019' verilerine göre, basın yayın ve gazetecilik iş kolunda kayıtlı 86 bin 366 işçiden sadece 6 bin 707'si sendikal güvenceye sahiptir. Türkiye bu oranlar nedeniyle OECD ülkeleri arasında son sıralarda yer almıştır (DİSK, 2019).

Türkiye'de basın yayın alanında 2013 yılından günümüze kadar sendikalaşma oranında her ne kadar artış olmuş gibi gözükse de toplu sözleşmeden yararlananların sayısında bir değişiklik olmamıştır. Bir başka ifadeyle iyileşme rakamlar bazında yaşanmış, fiili yaşantıda olumlu bir gelişme görülmemiştir. Medyada yıllardan beri en etkin sendika olan Türkiye Gazeteciler Sendikası, bu dönemde güç kaybetmiş, Anadolu Ajansı'ndaki üyelerin büyük bir bölümü, toplu halde yeni kurulan Medya-İş Sendikası'na geçiş yapmıştır. Hükümetin bazı bakanları ve ajansın üst yöneticilerinin, bu geçişi artırmaya dönük çabaları da olmuş ve söz konusu sendikanın hükümet tarafından bizzat kurulduğu iddiaları uzun bir süre kamuoyunda tartışılmıştır. Anadolu Ajansı'nda çalışan işçiler adına 2019 yılında yapılan toplu iş sözleşmesi görüşmelerinde ücret ve bazı sosyal haklarda geriye gidiş yaşanmıştır. Ajans çalışanlarının bir bölümü işten çıkarılmış, bir bölümü de yönetimin baskıları sonucu emekliye sevk edilmiştir. Aynı dönemde benzer uygulama TRT'de de 
yaşanmış, birçok kişinin işine son verilmiştir (Akkaya, 2019; Türkiye Gazeteciler Sendikası, 2019). Bu bağlamda dikkat çekici bir başka bilgi de ana akım medya olarak adlandırılan büyük medya gruplarının hiç birisinde sendikalı ve toplu sözleşmeli işçi bulunmamasıdır.

Enerji, finans, denizcilik, turizm ve telekomünikasyon gibi birçok sektörde faaliyet gösteren medya patronları, ekonomik kriz, yeniden yap1lanma ve elektronik gazeteciliğe geçiş gibi gerekçelerden dolayı gazetecilerin işlerine son vermektedir. Çalışma Bakanlığı'nın verilerine göre, 2001 ekonomik krizinden 2258 fikir işçisi işsiz kalmıştır (Özsever, 2003, s.141). Benzer bir durum ekonomik sorunların arttığ1 günümüzde yaşanmakta, basılı yayın hayatına son veren gazetelerin sayısı gün geçtikçe artmaktadır. Radikal, Haber Türk ve Vatan gibi ulusal çapta yayın yapan gazetelerin yanı sıra birçok yerel gazete kâğıt ve baskı maliyetlerinde yaşanan olağandışı artıştan dolayı kapanmış, bu kurumlarda görev yapan çalışanlar işsiz kalmıştır. Benzer şekilde ulusal televizyon ve radyo istasyonları da ekonomik nedenlerden dolayı yayın hayatlarına son vermiş ve basın sektöründeki işsiz sayısı artama devam etmiştir (Sözcü, 2018).

Türk basın tarihindeki en büyük mülkiyet değişimi, 2018 yılında yaşanmıştır. Ülkenin en büyük medya grubu olan Doğan Medya Grubu, Erdoğan Demirören'in sahipliğindeki Demirören Medya Grubu'na satılmıştır. Böylece 1979 yılında Milliyet gazetesini alarak medya patronu olan Aydın Doğan, 40 yıllık medya yaşamından çekilmiştir. Söz konusu yayın organlarında yönetici kadroları başta olmak üzere birçok kişinin işine son verilmiştir (Deutsche Welle, 2018).

Gazeteciler Cemiyeti'nin raporuna göre, geçmişte olduğu gibi günümüzde de fazla sayıda gazetecinin aldıkları ücretlerin tamamı bordroya yansitılmamakta, bu kişiler, asgari ücretten istihdam edilmektedir. Gazetecilerin emekli olurken mağdur edilmesine yol açan bu uygulama medyanın tamaminda yaygin bir uygulama olarak bilinmektedir. Kitle iletişim araçlarındaki tekelleşmenin yaygınlaşması, siyasi iktidarların baskıları sonucu büyüyen sendikasızlaşma harekâtı, medya mensuplarının iş güvenceleri olmadan çalışmasına yol açmıştır. Bu noktada önemli bir sorun da medya kuruluşlarının, hukuka aykırı olarak taşeron işçi çalıştırmaları olarak ortaya çıkmıştır (Gazeteciler Cemiyeti, 2019). 
Basın İş Kanunu olarak adlandırdığımız yasa, günümüz Türk medyasında büyük ölçüde işlevsizleştirilmiştir. Basının holdinglerle birlikte tekelleşme dönemine girmesiyle, medya yöneticileri, gelenekleri zorlamaya başlamış ve fikir işçilerine çalışma koşullarıyla ilgili kendi tercihlerini dayatma fursatı elde etmiştir. Bunun sonucunda, gazetecilerin hem meslek onurlarını zedeleyen hem de özgürlüklerini sınırlandıran bugünkü durum ortaya çıkmıştır. Bir anlamda, fiilen gazetecilik yapan, ama hukuk karşısında gazeteci sayılmayan medya çalışanları dönemi başlamıştır. Basın İş Kanunu yerine, 4857 sayılı İş Kanunu uygulanarak, gazetecilerin önemli bir bölümü de telif ücretiyle çalıştırılmak zorunda bırakılmaktadır. Böylelikle, patronlar, basın çalışanlarına karşı kıdem tazminatı ödeme yükümlülüğünden ve Sosyal Güvenlik Kurumuna ödemesi gereken primlerden kurtulmakta, bu arada gazetecinin sosyal güvenlik hakkı elinden alınmaktadır. İkili sözleşme imzalaması dayatılan gazeteciler, işsiz kalma endişesiyle bu sözleşmeleri imzalamaktadır (Şakar, 2008, s.11).

Günümüzde medya profesyonellerine ilişkin bir başka sorun ise, internet üzerinden dijital yayın yapan gazetecilerin büyük bir çoğunluğunun gazeteci olarak tanımlanmamasıdır. Anlık yayın yapan ve her gün binlerce, milyonlarca kişiye seslerini duyurabilen bu yayın organlarında çalışanlar, basın kartı alamamakta; basın kartı ve diğer yasal düzenlemelerin sağladığı sosyal haklardan yararlanamamaktadır.

Christensen, Türkiye'de Mülkiyetin Yoğunlaşması, Sendikaların Düşüşü ve Devlet Mevzuatı (2007, s.179) adlı çalışmasında Türk medyasına hâkim olan üç ana faktörün olduğunu belirtmektedir. Bunlar: Tekelleşme, medya sahiplerinin sendikanın etkisinin azaltılmasına neden olması ve yasaların etkisi ve gazetecilerin çalışma koşullarıdır. Dolayısıyla, Türkiye açısından bakıldığında medyanın kurumsal ve kuramsal olarak, diğer alanlarda olduğu gibi tam bir oturmamışlık düzeni içerisinde olduğunu söylemek mümkündür. Başka bir ifadeyle diğer kurumların düzeyi, medyanın da seviyesini belirlemektedir (Gezgin, 2002, s.13)

Sonuç olarak, Türkiye'de basın çalışanları açısından genel olarak çalışma koşulları, örgütlenme ve diğer ekonomik ve sosyal haklar alanında yaşanan sorunları birkaç başlık altında özetlemek mümkündür. Akkaya'ya (2019) göre bunlar şu şekilde sıralanmaktadır: 
- Anayasal bir hak olmasına karşın toplumun bilgilenmesi işlevini yerine getiren gazetecilerin birçok sosyal güvenceden yoksun olması,

- Çalışanların iş güvencesinin medya patron ve yöneticilerinin insafına terk edilmesi,

- Basında işsizlik ve düşük ücretle çalışmanın rekor seviyede olması,

- İletişim fakültesi mezunlarının istihdam edilmemesi ve gelecek güvencelerinin olmaması,

- Sosyal güvenlik haklarının devamlı olarak geriletilmesi,

- İtibari hizmet hakkının birçok kişiyi kapsam dışında bırakması.

\section{Basında İnsan Kaynağının Genel Özellikleri}

Medya sektöründe çalışanlarının sosyal ve ekonomik haklardan yeterince yararlandırılmaması, sektördeki insan kaynağını gelişimini olumsuz yönde etkilemektedir. Bu durum nitelikli iş gücünün basın alanında istihdam edilmesini sınırlandırmakta, istihdam edilenlerin de kendilerini geliştirmelerinin ve çağın gerektirdiği donanıma sahip olmalarının önünde engel teşkil etmektedir.

Türkiye'de medya çalışanlarının genel özelliklerine bakıldığında, iletişim fakültesi mezunlarının sektörde yeteri kadar istihdam edilmedikleri ortaya çıkmaktadır. Bu konuda radyo, televizyon ve dijital yayın organları ile ilgili sağlıklı bir veri bulunmamakla birlikte, yazılı basın organları için toplanan veriler önemli bir gösterge olarak kabul edilmektedir. Türkiye İstatistik Kurumu verilerine göre, 2018 yılında yazılı basın organlarında çalışanların sayısı bir önceki yıla göre yüzde 7 azalarak, 47 bin 149'a gerilemiştir. Başka bir ifadeyle 7 bin kişi işsiz kalmıştır. Bu dönemde istihdam edilenlerin yüzde 64'ünü erkek, yüzde 36'sını kadın çalışanlar oluşturmaktadır (Anadolu Ajansı, 2019). Aynı dönemde çalışanların yüzde 55'i ilköğretim ve lise mezunuyken, yüzde 45'i fakülte veya yüksekokul mezunudur. İletişim fakültesi mezunlarının toplam çalışanlar içindeki oranı ise yüzde 15'te kalmaktadır (Basın İlan Kurumu, 2019).

Eğitimli iş gücünün medya sektöründe yeterince istihdam edilmemesi, basın ürünlerinin kalitesi üzerinde olumsuz etki oluşturmaktadır. İletişim teknolojilerinin devamlı olarak ilerlemesi, bilgi ve haber alıp verme şekillerinin değişmesine yol açmıştır. Artık günümüzde bilgilerin 
elde edilmesi, tasnif edilmesi ve sunulması aşamaları farklı uzmanlık gerektiren konular haline gelmiştir. Dolayısıyla bu fonksiyonu yerine getiren gazetecilerin, kendi alanlarında uzman olması mesleki bir zorunluluk olarak ortaya çıkmıştır. Ancak iş güvencesi yoksunluğu, tatmin edici ücretlerin ödenmemesi ve gazetecilerin her an işsiz kalma riski ile karşı karşıya bulunması, nitelikli iş gücünün ve iletişim fakültesi mezunlarının bu mesleğe yönelmesini zorlaştırmaktadır. Mevcut çalışanların kendilerini yenilemeleri ve çağımızın gerektirdiği donanıma erişmeleri de bu koşullar altında kolay olmamaktadır. Bu nedenle ortaya konan haber ve yorum gibi basın ürünlerinin kalitesi sorgulanmaktadır.

Görüleceği üzere ülkemizde medya patronları, teknolojik gelişmelere yaptıkları yatırımı insan kaynağından esirgemektedir. Yine benzer şekilde ekonomik dengelere gösterilen özen, haber ve bilgi akışının nitelikli olması için sarf edilmemektedir. Meslek içi eğitim ve çalışanların çağın gerektirdiği donanıma ulaşmalarını sağlama noktasında ise hiçbir adım atılmamaktadır (Yücedoğan, 2012, s.110-111). Bu bağlamda önemli bir eleştiri de iletişim fakülteleri ve bu fakültelerde verilen eğitime yönelik olarak yapılmaktadır. Gerek dünyada gerekse Türkiye'de iletişim eğitiminin içeriği ile ilgili tartışmalar, toplumun ve sektörün ihtiyaç ve beklentilerinin karşılanamaması noktasında yoğunlaşmaktadır (Güz vd., 2017; s. 1555).

Basında iş güvencesinin olmaması, medyanın en önemli özelliği olan basın özgürlüğü ile de yakından ilişkili olan bir konudur. İşsiz kalma endişesi bulunan gazetecilerin, haber ve yorumlarında rahat hareket edemeyeceği, kendi kendine sansür uygulayabileceği kabul edilen bir gerçektir. Basın özgürlügünün, tarihsel gelişimine uygun olarak yalnızca Devlet müdahalesine karşı korunan bir hak olarak düşünülmesi doğru değildir. Serbest rekabet ilkeleri doğrultusunda ticari faaliyette bulunan basın işletmelerinde çalışan gazetecilerin özgürce çalışabilmesini sağlamak için, hem işverenler, hem de diğer kolektif güçlere karşı de korunması gerekmektedir. Bu koruma kalkanının amacı, gazetecinin gerçekleri ifade ederken herhangi bir baskı altında kalmamasını sağlamak, karşılaşacağ1 riskleri minimize etmektir. Böylece gazetecinin özgürlügünün işverene karşı korunması sağlanarak, kamu yararına hareket etmesi güvence altına alınacaktır. (Karaca ve Banar, 2012, s.11). 
Gazetecinin, geçimine ve insan onuruna yaraşır bir yaşam sürdürmesine yetecek düzeyde düzenli gelirinin olması ve bu geliri sadece gazetecilik faaliyetinden elde etmesi: basın ve ifade özgürlüğü açısından önemli bir gerekliliktir. Bu nedenle gazetecinin asli işi olan gazetecilik dişında gelir elde etmek amaciyla başka işlerle yönelmemesi büyük önem taşımaktadır. Bir medya mensubunun başka işler yapmaya kalkışması, tarafsızlığına gölge düşürebileceği gibi, bu tutumu basın özgürlüğüyle bağdaşmayacak ve mesleğini dış etkenlerin baskısı altında sürdürmesine neden olabilecektir. Unutulmamalıdır ki iş güvencesinden yoksun, sosyal haklarını elde edemeyen gazetecilerin, sansürsüz ve özgür gazetecilik faaliyetleri yürütmeleri mümkün değildir. Bu nedenle gazetecilerin sendikalı çalışma hayatına dâhil olmaları sağlanmalıdır (Gazeteciler Cemiyeti, 2019).

\section{Sonuç}

Türk basını, geçmişten günümüze kadar birçok sorunla karşı karşıya bulunmaktadır. İç içe geçmiş bu sorunlar arasında en az gündeme getirilen konu ise basın işçilerinin çalışma koşulları ve iş güvencesi sorunudur. Oysa gazetecilerin iş güvencesine sahip olması, hem basın ürünlerinin kalitesi hem de basın özgürlügü üzerinde son derece etkili bir faktördür.

İlk dönemlerden itibaren güç koşullar altında görev yapan Türk gazetecileri, kâğıt üzerinde de olsa yasal haklarına 1952'de yürürlüğe giren kanun ile kavuşmuşlardır. Bu dönemden itibaren yasal hak arayışı başlarken, Türkiye'de ilk toplu iş sözleşmesi 2 basın kuruluşu ile 1964'te yapılmıştır. Bu tarihte kurulan Türkiye Gazeteciler Sendikası, 70'li yıllar boyunca sektörde örgütlenmiş ve birçok kurumda toplu iş sözleşmesine imza atmıştır. Ancak 12 Eylül 1980 darbesi, tüm iş kollarında olduğu gibi basın iş kolunda da sendikal örgütlenmeye darbe vurmuş ve çalışanlar önemli hak kaybına uğramışlardır.

Medyada tekelleşmenin ve mülkiyet değişikliklerinin başladığı bu yıllarda savunmasız olan gazeteciler kimi zaman işlerini kaybetmiş kimi zaman da farklı iş kollarından sigortalatılarak hak kaybına uğratılmıştır.

Türk basınında, iş güvencesi ile aynı anlamı taşıyan sendikalaşma oranında hiçbir zaman istenilen seviyeye ulaşılamamıştır. Basın iş ko- 
lunda sendikalaşma oranı yüzde 8 civarında gerçekleşmiş, toplu iş sözleşmesinden yararlanan gazetecilerin oranı ise bu rakamın bile çok gerisinde kalmıştır. Türkiye bu oranla OECD ülkeleri arasında son sırada yer almıştır. Bu durum gazetecileri olumsuz etkilemiş, Anadolu Ajansı ve TRT gibi kamu kurumlarında bile fikir iş̧̧ileri önemli hak kaybına uğramıştır. 2018 yılında Türkiye'nin medya alanında yaşanan en büyük mülkiyet değişikliğinde, Doğan Holding'e ait medya kuruluşları, Demirören Holding'e devredilmiş, iş güvencesinden yoksun birçok gazeteci işsiz kalmıştır.

Sonuç olarak Türkiye'de basın sektöründe çalışma koşulları, örgütlenme ve diğer ekonomik ve sosyal haklar alanında; gazetecilerin sosyal güvenceden yoksun olması, çalışanların iş yaparken medya patronlarının insafına terk edilmesi, işsizlik rakamlarının yüksek olması, nitelikli iş gücünün istihdam edilmemesi, çalışanların sosyal güvenlik haklarının devamlı olarak geriletilmesi gibi sorunlar bulunmaktadır.

Medya mensuplarının çalışma koşullarında ortaya çıkan bu olumsuzluklar, bu sektördeki insan kaynağının kalitesini de olumsuz yönde etkilemektedir. Nitelikli iş gücünün istihdamı ve özellikle iletişim fakültesi mezunlarının sektöre girişi mümkün olamamaktadır. Yazılı basında istihdam edilenlerin sadece yüzde 15'nin iletişim fakültesi mezunu olması, bu durumun önemli bir göstergesi olarak yorumlanmaktadır.

Basında iş güvencesi yoksunluğu, basın özgürlüğü açısından da önemli bir sorun olarak karşımıza çıkmaktadır. İşsiz kalma endişesi ve işinden yeterli oranda ücret alamayan gazetecinin kamu çıkarlarına uygun olarak gazetecilik yapamayacağı günümüzde kabul edilen bir gerçektir. İş güvencesi olmayan, sosyal haklarını elde edemeyen gazetecilerin, sansürsüz ve özgür bir gazetecilik faaliyeti yürütemeyeceği gerçeğinden hareketle, Türkiye'deki basın çalışanları bu açıdan mutlaka bir koruma altına alınmaya ihtiyaç duymaktadır. 


\title{
EXTENDED ABSTRACT
}

\section{Problems Associated with Working Life and Employment Security in Turkish Press}

\author{
Mehmet Sena Kösedağ \\ Erciyes University
}

Turkish press has been encountered with many issues from past to present times. When reviewing through the perspective of historical process, imposing restrictions on liberty of press by censoring severely the press products and instruments in various periods, acquisition of the press organs and enterprises by the capital within time, monopolization in press and failure to comply with the ethical rules and code of conduct in press are encountered by us as main issues. Furthermore, the issue of employment security encountered by the journalists due to economic problems experienced in press and unfair practices of press enterprises have been making an appearance as a substantial problem. However, this problem was not brought forward sufficiently on both the academic studies and media organs. As to be acknowledged by the outcome of this study, numerous journalists become unemployed in Turkish media from past to present and the ones maintaining their employed status have been carrying out their professions not only under unfavorable employment conditions but also as deprived of satisfactory employment security. Acquisition of media organizations by substantial capital groups shed more heat than light to this adverse circumstance. Press organs have laid their hands on cutting-edge equipment and technology required by the modern era in terms of technical and physical infrastructure, however, the very same development was failed to be reflected on the rights and working conditions of the employees.

The negativities of the working life in Turkish media have exactly been reflected on the union figures. Turkish journalists retrieved their legal rights for the first time by a law enacted in 1952. However, this law failed to achieve a decent execution field. The Journalists' Union of Turkey, established on this date, has been organized within the sector thro- 
ughout the 70s and concluded collective labor agreements in various organizations. However, the military coup d'état of September 12, 1980 dealt a major blow to unionization in the line of business of press just like every other line of business and employees experienced a substantial loss of right. Upon commencement of monopolization and change of property titles in the media, the journalists, becoming vulnerable during these years, have sometimes lost their jobs and sustained loss of right by being insured in various lines of business. The unionization today in press sector has realized as around 8 percent, and the ratio of the journalists benefiting from the collective labor agreements have fallen way behind this figure. Turkey, with this ratio, has ranked bottom among the OECD countries. This situation has adversely affected the journalists and even the white-collar employees performing their duties in enterprises and organizations of public broadcasting have sustained substantial loss of right.

In this study, the personal rights of press employees, becoming a substantial issue, are addressed and it is endeavored to reveal the influence of this situation on the liberty of press. In the study, where the response is sought for the question whether the qualified personnel recruitment is feasible or not within media sector, where the employment security is quite insufficient, it is aimed to further reveal the profile of the personnel employed in Turkish press sector in our times. In the first part of the study realized by means of literature review method, an overall framework related to the working life within the press is established and the legislative regulation determining the working life within the sector is addressed. Then, the general characteristics of the human resources performing duties within the Turkish press are referred and it is discussed to what extent the employment security affects the liberty of freedom and human resources.

In conclusion, issues such as the fact that the journalists are deprived of social security, employees left to the tender mercies of the media moguls while performing their professions, high unemployment rate, unable to employ qualified labor force, setbacks of social security rights of the employees on a continuous basis are certain major problems encountered within the working conditions, the organization in the press sector in Turkey and in the field of other economic and social rights. 
These emergent negativities within the working conditions of the media members do have an adverse effect on the quality of the human resources within this sector. Therefore, employment of the qualified work force and particularly the introduction of the graduates of faculty of communication is considered to be infeasible.

Lack of employment security within the press appears before us as a substantial problem also in terms of liberty of freedom. It is fact well accepted by everyone that a journalist with the anxiety of unemployment and unable to receive adequate salary is unlikely to duly perform journalism. Considering the fact that the journalists with lack of employment security and unable to achieve their social rights shall fail to execute and perform uncensored and independent journalism, the press employees in Turkey certainly require to be taken under protection in this respect.

Except the struggle initiated by the journalists in Turkey in 1961 against the common actions of media moguls, it is further established with this study that they fail to take steps towards a collective initiative for the purpose of achieving their rights. It is also observed that there is a dramatic organization problem within the Turkish press, the existing organizations are actually structured in a disorganized manner and most of them fail to endeavor in the favor of the white-collar employees due to clashing with each other. Beginning with the establishment of a puissant structure by the professional associations of press by acting collectively, initiation of a struggle against the political power and media moguls by identifying the professional and economic issues and raising awareness of the employees at this point can be complied as acts to be performed at this point.

\section{Kaynakça / References}

Akkaya, Y. (2019). Türkiye'de çalışma yaşamının sorunları ve sendikal hak ihlalleri, 5 Mart 2019 tarihinde http://www.sosyalhaklar.net/2014/bildiriler/akkaya.pdf adresinden erişilmiştir.

Anadolu Ajansı (2109). Türkiye'de yazılı basında erkekler çoğunlukta adlı haber, 8 Nisan 2019 tarihinde https://www.aa.com.tr/tr/turkiye/yazilibasinda-erkekler-cogunlukta/1215366 adresinden erişilmiştir. 
Basın İlan Kurumu (2019). Basın İlan Kurumu 2018 basın çalşanları istatistikleri açılandı adlı haber, 9 Nisan 2019 tarihinde https://www.bik.gov.tr/basin-ilan-kurumu-2018-basin-calisanlariistatistikleri-aciklandi adresinden erişilmiştir.

Christensen, C. (2007). Concentration of ownership the fall of unions and government legislation in Turkey, Global Media and Communication, 3(2), 179-199.

Özbek, C. (Mayıs 24, 2018), Doğan grubundaki tasfiyelerin perde arkası haberi, Deustche Welle, 12 Mayis 2019 tarihinde https://www.dw.com/tr/sat\%C4\%B1lan-do\%C4\%9Fan-grubundakitasfiyelerin-perde-arkas\%C4\%B1/a-43909723 adresinden erişilmiştir.

Çakır, H. (2007). Gazeteciliğe giriş. Konya: Tablet Yayınları.

Erdoğan, İ. (2007). Türkiye'de gazetecilik ve bilim iletişimi. Ankara: Gazi Üniversitesi İletişim Fakültesi Yayınları.

Gazeteciler Cemiyeti (2019). Türk Basının Sorunları Raporu, (Rapor No:1, Rapor tarihi: 2014), 1 Mart 2019 tarihinde http://www.gazetecilercemiyeti.org.tr/gazeteciler-cemiyetinin-turkbasinin-sorunlari-raporu-yayinlandi adresinden erişilmiştir.

Gezgin, S. (2002). Medyanın Toplumsal İşlevi ve Kamuoyu Oluşumu, İstanbul Üniversitesi İletişim Fakültesi Dergisi, 1(12),11-20.

Güz, N. Yanık, H. ve Yegen, C. (2017). İletişim fakülteleri eğitim sistemine yönelik yeni bir yaklaşım. International Journal of Social Sciences and Education Research. 3(5), 1547-1560.

İngur, M. N. (2005). Basın yayın tarihi (5. Basım). İstanbul: Der Yayınları.

Karaca, G.N. ve Banar, S. (2012). Medyada çalışma hayatı. Eskişehir: Anadolu Üniversitesi Yayını No: 2512.

Karahisar, T. (2019). Türkiye'de gazetecilerin sendikalaşma sorunları. İletişim Fakültesi Dergisi, 33, 83-102. 2 Mart 2019 tarihinde https://dergipark.org.tr/download/article-file/212188 adresinden erişilmiştir.

Kösedağ, M.S. (2016). Çok partili dönemden günümüze yazılı basın alanında yapılan yasal düzenlemeler ve bunların basında temsili. Yayımlanmamış Doktora Tezi, Erciyes Üniversitesi SBE Enstitüsü, Kayseri.

Özsever, A. (2004). Tekelci medyada örgütsüz gazeteci. Ankara: İmge Kitabevi.

Sözcü. (Kasım 3, 2018). Gazeteler neden birer birer kapanıyor? 10 Mayıs 2019 tarihinde https://www.sozcu.com.tr/2018/ekonomi/gazeteler-nedenbirer-birer-kapaniyor-2715864/ adresinden erişilmiştir. 
Şakar, M. (2008). Basın iş sözleşmesinin sona ermesi ve kıdem tazminatı, Çalışma ve Toplum, 2(17), 11-29.

Topuz, H. (2003). II. Mahmut'tan holdinglere Türk basin tarihi (1. Basım). İstanbul: Remzi Kitapevi.

Topuz, H. (2014). II. Mahmut'tan holdinglere Türk basın tarihi (5. Basım). İstanbul: Remzi Kitapevi.

Tuncay. A.C. (1989). Hukuki yönden basında işçi-işveren ilişkileri, Evrim Basım Dağıtım Hukuk dizisi, No:13.

Türkiye Gazeteciler Sendikası (2019). 2 Nisan 2019 tarihinde, https://tgs.org.tr/aa-calisanlarina-cagri-bu-oyunu-bozalim adresinden erişilmiştir.

Ulusoy, B. (2012). Gazeteci ve Yasal Hakları. İstanbul Üniversitesi İletişim Fakültesi Dergisi, 1(12), 333-341. 17 Mart 2019 tarihinde http://dergipark.org.tr/iuifd/issue/22891/244962 adresinden erişilmiştir.

Yücedoğan, G. (2012). Basın, özgürlük ve gazeteci, İstanbul Üniversitesi İletişim Fakültesi Dergisi, Istanbul University Faculty of Communication Journal, 0(9). doi:http://dx.doi.org/10.17064/iüifhd.05736

\section{Kaynakça Bilgisi / Citation Information}

Kösedağ, M. S. (2019). Türk Basınında çalışma hayatı ve iş güvencesi sorunu. OPUS-Uluslararası Toplum Araştırmaları Dergisi, 13(19), 2479-2498. DOI: 10.26466/opus.579499 